Article

\title{
Investigation of Earth-Abundant Oxygen Reduction Electrocatalysts for the Cathode of Passive Air-Breathing Direct Formate Fuel Cells
}

\author{
Francisca E. R. Oliveira (D), Nelson A. Galiote ${ }^{(D)}$ and Fabio H. B. Lima * (D) \\ Institute of Chemistry of Sao Carlos, University of Sao Paulo, Av. Trabalhador Saocarlense, 400 CP 780, \\ São Carlos SP 13566-590, Brazil; elenicequimica@gmail.com (F.E.R.O.); nags13@gmail.com (N.A.G.) \\ * Correspondence: fabiohbl@iqsc.usp.br; Tel.: +55-16-3373-8681
}

Received: 30 June 2018; Accepted: 29 July 2018; Published: 6 August 2018

\begin{abstract}
The development of direct formate fuel cells encounters important obstacles related to the sluggish oxygen reduction reaction (ORR) and low tolerance to formate ions in Pt-based cathodes. In this study, electrocatalysts formed by earth-abundant elements were synthesized, and their activity and selectivity for the ORR were tested in alkaline electrolyte. The results showed that carbon-encapsulated iron-cobalt alloy nanoparticles and carbon-supported metal nitrides, characterized by transmission electron microscopy (TEM) and X-ray diffraction (XRD), do not present significant activity for the ORR, showing the same half-wave potential of Vulcan carbon. Contrarily, nitrogen-doped carbon, synthesized using imidazole as the nitrogen source, showed an increase in the half-wave potential, evidencing an influential role of nitrogen in the ORR electrocatalysis. The synthesis with the combination of Vulcan, imidazole, and iron or cobalt precursors resulted in the formation of nitrogen-coordinated iron (or cobalt) moieties, inserted in a carbon matrix, as revealed by X-ray absorption spectroscopy (XAS). Steady-state polarization curves for the ORR evidenced a synergistic effect between Fe and Co when these two metals were included in the synthesis (FeCo-N-C material), showing higher activity and higher limiting current density than the materials prepared only with Fe or Co. The FeCo-N-C material presented not only the highest activity for the ORR (approaching that of the state-of-the-art $\mathrm{Pt} / \mathrm{C}$ ) but also high tolerance to the presence of formate ions in the electrolyte. In addition, measurements with FeCo-N-C in the cathode of an passive air-breathing direct formate fuel cells, (natural diffusion of formate), showed peak power densities of 15.5 and $10.5 \mathrm{~mW} \mathrm{~cm}^{-2}$ using hydroxide and carbonate-based electrolytes, respectively, and high stability over $120 \mathrm{~h}$ of operation.
\end{abstract}

Keywords: oxygen reduction; non-noble metal electrocatalysts; M-N-C; direct formate fuel cells

\section{Introduction}

The utilization of more efficient energy storage or conversion devices such as fuel cells, batteries, and photo-electrochemical systems are decisive for the development of a sustainable society and may help to decrease the carbon dioxide emissions to the atmosphere [1]. Fuel cells offer many advantages related to their high energy conversion efficiency and autonomy. Over the years, researchers have considered formate ions as fuel to power direct liquid alkaline fuel cells [2,3] due to advantages associated with its low toxicity, non-volatility, and easy storage and transportation handling. Besides, formate can be produced via carbon dioxide electrochemical reduction. Therefore, its production in $\mathrm{CO}_{2}$ electrolyzers, followed by its consumption of fuel cells, constitute a regenerative cycle of electrochemical energy conversion and storage [4]. Direct formate fuel cells (DFFC), with alkaline electrolyte, were already used in Europe in the 1960s to power a television tower in the mountains in 
Switzerland and operated for about $7000 \mathrm{~h} \mathrm{[5].} \mathrm{In} \mathrm{alkaline} \mathrm{electrolyte,} \mathrm{the} \mathrm{formate} \mathrm{electro-oxidation}$ and the oxygen reduction reaction (ORR) takes place following the Equations (1) and (2), respectively. The theoretical potential difference is $1.45 \mathrm{~V}$, which is $0.31 \mathrm{~V}$ higher than that of the direct ethanol fuel cell (DEFC), and $0.24 \mathrm{~V}$ higher than that of the direct methanol fuel cell (DMFC).

$$
\begin{gathered}
2 \mathrm{HCOO}^{-}+2 \mathrm{OH}^{-} \rightarrow 2 \mathrm{CO}_{2}+2 \mathrm{H}_{2} \mathrm{O}+4 \mathrm{e}^{-} \quad \mathrm{E}^{0}=-1.05 \mathrm{~V} \\
\mathrm{O}_{2}+2 \mathrm{H}_{2} \mathrm{O}+4 \mathrm{e}^{-} \rightarrow 4 \mathrm{OH}^{-} \quad \mathrm{E}^{0}=0.4 \mathrm{~V}
\end{gathered}
$$

The $\mathrm{CO}_{2}$ molecules, produced in the anode, will react with the $\mathrm{OH}^{-}$species, from the electrolyte, resulting in $\mathrm{CO}_{3}{ }^{2-}$. The additional reaction of $\mathrm{CO}_{3}{ }^{2-}$ with $\mathrm{CO}_{2}$ will produce $\mathrm{HCO}_{3}{ }^{-}$. Therefore, prolonged operation of the fuel cell will convert the cell electrolyte to bicarbonate, and this decreases the performance of the cell, especially due to the diminished ORR kinetics. However, as proposed by Enyo and co-authors [6], this disadvantage can be overcome by using electrolytes initially formed by carbonate instead of hydroxyl ions, since its product, $\mathrm{HCO}_{3}{ }^{-}$, can be thermally decomposed at temperatures above $80^{\circ} \mathrm{C}$, regenerating the $\mathrm{CO}_{2}$ and the $\mathrm{CO}_{3}{ }^{2-}$ species.

Efforts have been done to develop fuel cell electrocatalysts formed by earth-abundant elements. Besides Pt, Pd-based electrocatalysts are also active for the electrochemical oxidation of formate in alkaline media [6-10], which is interesting for practical applications. For the cathode, remarkable progress in non-precious metal catalysts (NPMC) has been accomplished in the last decades [11]. The first study was published by Jasinski, in 1964, reporting the performance of cobalt phthalocyanines in alkaline media [12]. This was followed by other studies with metal-containing macrocycles and macrocycles-derived electrocatalysts [13-15]. Among the challenges, the increase in activity and durability of these electrocatalysts are the most difficult challenge to attain. Until now, the most promising electrocatalysts for the ORR are based on nitrogen and transition metal "co-doped" carbon catalyst, also designed as nitrogen-coordinated iron (and/or cobalt) embedded on a carbon matrix (M-N $\mathrm{N}_{4}$ species), generally represented by $\mathrm{M}-\mathrm{N}-\mathrm{C}(\mathrm{M}=\mathrm{Fe}$ and/or Co). This high activity is mostly attributed to the specific $\pi$-conjugation structure and the polarization of the atoms bonded to the carbon matrix, transforming these species in good electron donors and in adsorption sites facilitating the ORR [16-19]. According to different authors, the performances for the ORR are directly related to the electrocatalyst composition and structure such as, for example, M- $\mathrm{N}_{4}$ moieties [20,21], carbon-encapsulated iron/iron carbide nanoparticles [22], nitrides [23], N-doped carbon-encapsulated metal nanoparticles [24], phosphides [19], and oxides [25]. However, in a typical synthesis via pyrolysis, the formation of these different structures greatly depends on the synthesis condition [26], ligand nature and structure (chelating nitrogen atom source such as imidazole [27], 1,10-phenanthroline [28], and others nitrogen-rich molecules [29,30]), carbon support [31], pyrolysis temperature [14], and thermal treatment atmosphere [16]. Nevertheless, the composition and structure of the active site for the ORR is not well understood and this topic is still under debate. Ganesan, et al. [32] concluded that the presence of Fe is crucial for obtained electrocatalysts with high activity for the ORR. However, other studies observed similar activity for the ORR for $\mathrm{N}$-doped carbon nanostructures (metal-free material) and N-coordinated iron-carbon electrocatalysts, in acid media $[33,34]$. Also, some researchers claim that $\mathrm{N}$-doped carbon-encapsulated iron nanoparticles are highly active for the ORR alone or in synergistic effect with $\mathrm{Fe}-\mathrm{N}_{4}$ neighboring sites $[22,35,36]$. These controversial and complex results arise from the fact that, during the pyrolysis procedure, in addition to M-N-C species, metal nitrides, metallic nanoparticles, carbon-encapsulated, and N-doped carbon-encapsulated metallic nanoparticles are also produced. This leads to materials that are structurally different, and possess different active sites for ORR, with different electrocatalytic activities $[20,21,30]$. Therefore, this is an intrinsic difficulty to understand the structures that govern the activity of the ORR in this kind of materials.

Here, it is reported the synthesis, characterization, and the electrocatalytic activity of electrocatalysts constituted of nitrogen-coordinated iron and/or cobalt embedded on carbon matrix 
(Fe, Co or FeCo-N-C) for the ORR, in alkaline media. Intentionally, some nanostructures, commonly produced during the pyrolysis step, were also synthesized, and their activities for the ORR were compared to that of the FeCo-N-C material. Additionally, it is presented the results for the ORR electrocatalysis in the presence of formate ions, in different electrolytes with different $\mathrm{pHs}$, and the performance and stability of the $\mathrm{FeCo}-\mathrm{N}-\mathrm{C}$ material as the cathode electrocatalyst in passive air-breathing direct formate fuel cells.

\section{Results and Discussion}

\subsection{Electrocatalyst Characterization}

Figure 1A shows the XRD spectra obtained for the as-prepared Fe-N-C, Co-N-C, and FeCo-N-C materials, and Figure 1B presents the XRD spectra for the same materials but submitted to the acidic treatment. The diffractogram for Vulcan carbon was included for comparison. In Figure 1A, it is possible to observe the presence of oxides, metallic nanoparticles, nitrides and carbides (some peaks are overlapped). Considering that some of these structures were reported to be active for the ORR, especially in alkaline media $[23,24,37,38]$, the acid treatment was conducted in order to remove most of these secondary structures. It is noted that the diffraction patterns in (B) are similar for all samples. The observed peaks at $25^{\circ}$ and $44^{\circ}$ are ascribed to the reflections of the (002) graphite carbon planes. The low-intensity sharp peak positioned at $2 \theta=45^{\circ}$, that overlaps with the second carbon diffraction peak $\left(44^{\circ}\right)$, evidences the existence of metallic Fe and Co nanoparticles (which are encapsulated by carbon, as will be observed in TEM images hereafter). The formation of these encapsulated nanoparticles is explained by a graphitization process catalyzed by metallic iron and/or metallic cobalt atoms at high temperature [22]. Here, it is worth to mention that nitrogen-coordinated Fe and/or Co atoms in the carbon matrix species (M-N-C) are amorphous and, so, do not present diffraction peaks. Therefore, it is concluded that most of the metal oxides, nitrides, carbides, and unprotected or partially carbon-covered metallic nanoparticles (produced during the first heat treatment in $\mathrm{N}_{2}$ or Ar [22]), are eliminated in the acidic treatment, as their diffraction peaks vanished. The $\mathrm{XRD}$ for the $\mathrm{FeCoO}_{x} / \mathrm{C}$ material, shown in Figure S2, presents overlapped peaks attributed to $\mathrm{Fe}_{3} \mathrm{O}_{4}$ and $\mathrm{Co}_{3} \mathrm{O}_{4}$. For the FeCo@C material (carbon-encapsulated nanoparticles), peaks related to the formation of FeCo alloy $\left(\mathrm{Co}_{7} \mathrm{Fe}_{3}\right)$ are apparent at approximately $45^{\circ}, 65^{\circ}$, and $83^{\circ}$, accompanied by satellite peaks related to the presence of Fe carbides (see figure inset for the details). The diffractogram for the $\mathrm{Fe}_{x} \mathrm{~N}$ material shows the formation of a pure iron nitride phase, $\mathrm{Fe}_{2} \mathrm{~N}$, showing that the synthesis method was efficient for the nitridation process. For nitrogen-doped carbon material, N-C, as expected, no diffraction peaks are discerned, and its profile is similar to that obtained for Vulcan carbon. One point that should be stressed here is that synthesis routes used to prepare the secondary species ( $\mathrm{FeCo} @ \mathrm{C}, \mathrm{Fe}_{\mathrm{x}} \mathrm{N}$, etc) were very selective, and they are unlike to produce any $\mathrm{M}-\mathrm{N}-\mathrm{C}$ species.

Figure 2 shows the TEM images of (A) Fe-N-C, (B) Co-N-C, and FeCo-N-C (C) before and (D) after the acid treatment (FeCo-N-C AT). It is possible to note the presence of nanoparticles, and nanoparticles with an encapsulating graphitic carbon layer for the as-prepared materials. After the acid treatment, it is noted a significant reduction of the number of nanoparticles, but it is still apparent that some carbon-encapsulated nanoparticles remain in the sample, evidencing that the carbon layers protect the nanoparticle from corrosion, at least for those with complete encapsulation. EDX measurements obtained before and after the acid treatment of the $\mathrm{FeCo}-\mathrm{N}-\mathrm{C}$ material is presented in Table 1. The results show that the amounts of Fe and Co were 5.0 and $4.6 \mathrm{wt} . \%$ before, and 3.1 and $2.8 \mathrm{wt} . \%$ after the acid treatment, respectively. Considering that there are still some encapsulated nanoparticles after the acid treatment (Figure 2D), which is responsible for the distinctive diffraction peak at approximately $44^{\circ}$ in Figure 1B, it is probable that the most part of the remaining metallic atoms is in those nanostructures. In fact, this attests that the graphitic carbon layers act as a protective barrier against the proton corrosion, at least for those nanoparticles that are completely encased. However, as will be discussed below, these encapsulated nanoparticles do not show a significant 
electrocatalytic activity for ORR at high potentials. In the TEM images of the synthesized FeCo@C material (carbon-encapsulated FeCo nanoparticles), shown in Figure S3, as desired, it is only seen the existence of nanoparticles fully encapsulated by the carbon layers, totally bound to the nanoparticles (with "adhesion" throughout the nanoparticle). This is due to the compatibility of the metal or the metal carbide lattice parameters with that of the graphitic carbon layer as noted before [39-43]. Therefore, this material can be used as "blank" to disclose its contribution to the ORR activity of the FeCo-N-C electrocatalyst, as will be shown in the next section.

The characterizations presented so far do not specify if part of the remaining Fe and/or Co atoms are coordinated by nitrogen, forming $\mathrm{M}-\mathrm{N}-\mathrm{C}$ structures. So, the $\mathrm{FeCo}-\mathrm{N}-\mathrm{C}$ material was also characterized by XAS measurements, and the obtained results are represented in Figure 3. The XANES (X-ray Absorption Near Edge Structure) measurements (Figure 3A,C), in the Fe and Co K edges, show that the spectra have similarities with the spectra for bulk Fe or Co (the spectra for Fe and Co foils were included for comparison), but with distinctions in the magnitudes of the pre- and the main edges. Additional information can be extracted from the FT of the EXAFS (Extended X-ray Absorption Fine Structure) oscillations, presented in Figure 3B,D, in which it is noted that the FTs for FeCo-N-C in both, Fe and Co edges, have the same peaks centered at ca. 2.1 $\AA$, related to the Fe-Fe and Co-Co first coordination shell. This is ascribed to the presence of carbon-encapsulated FeCo nanoparticles in the sample [36]. Also, it is observed a "shoulder" centered at $1.5 \AA$ for both absorption edges, and this can be related to the coordination of Fe or $\mathrm{Co}$ and atoms with low-atomic numbers, such as $\mathrm{N}$ or O. Despite this shoulder at $1.5 \AA$ has its intensity disturbed due to the peak at $2.1 \AA$, this fact is an evidence of the formation of the Fe-N and Co-N coordination in the FeCo-N-C material.
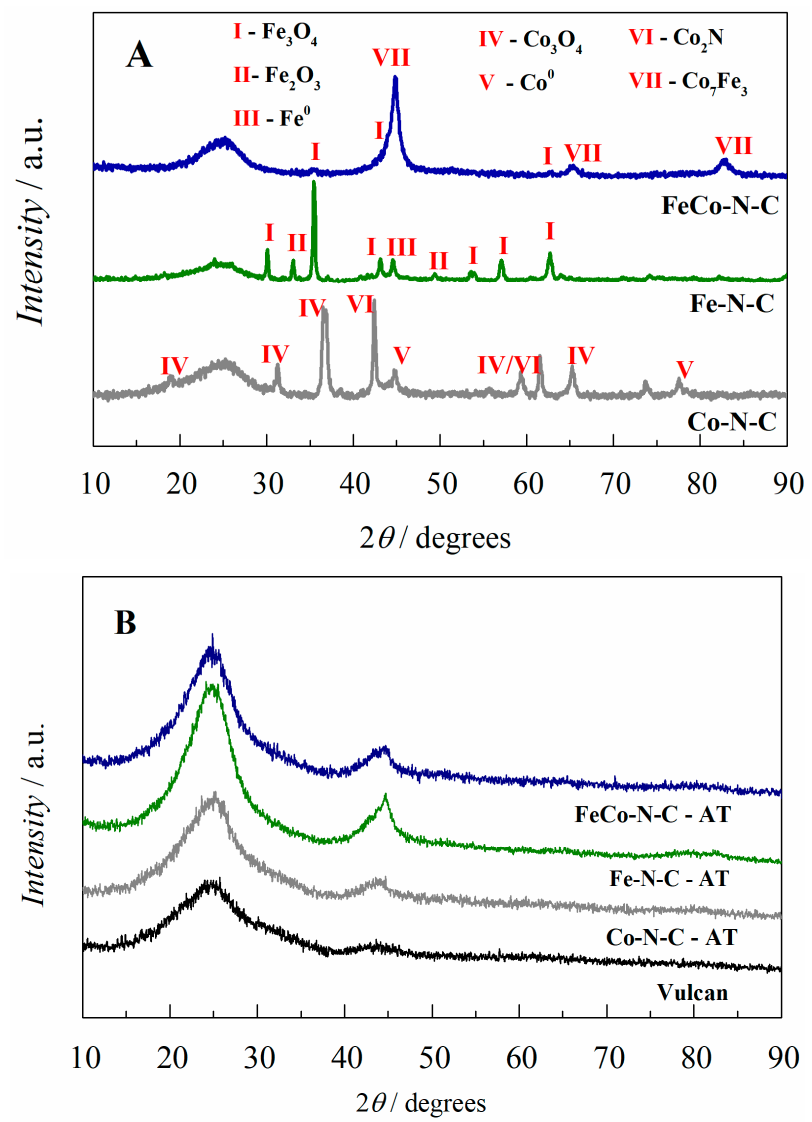

Figure 1. X-ray diffractograms obtained for (A) Fe-N-C, Co-N-C and FeCo-N-C, and (B) for the same electrocatalysts but after acid treatment. The result obtained for Vulcan carbon is shown for comparison. 

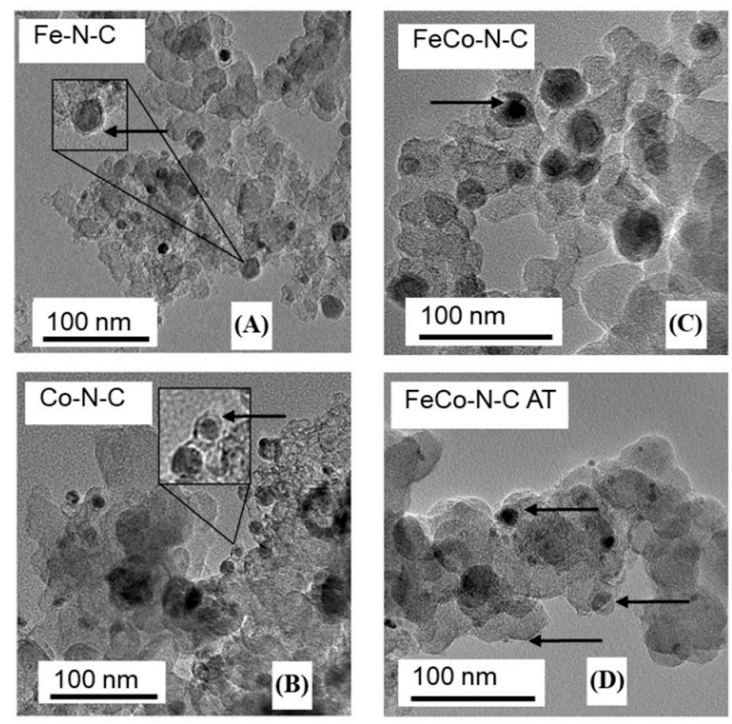

Figure 2. Transmission Electron Microscopy images of (A) Fe-N-C and (B) Co-N-C, (C) FeCo-N-C, and (D) FeCo-N-C AT showing that carbon-encapsulated Fe and/or Co nanoparticles are also formed during the synthesis. The arrows indicated the graphitic carbon layers. AT refers to the acid treated sample.
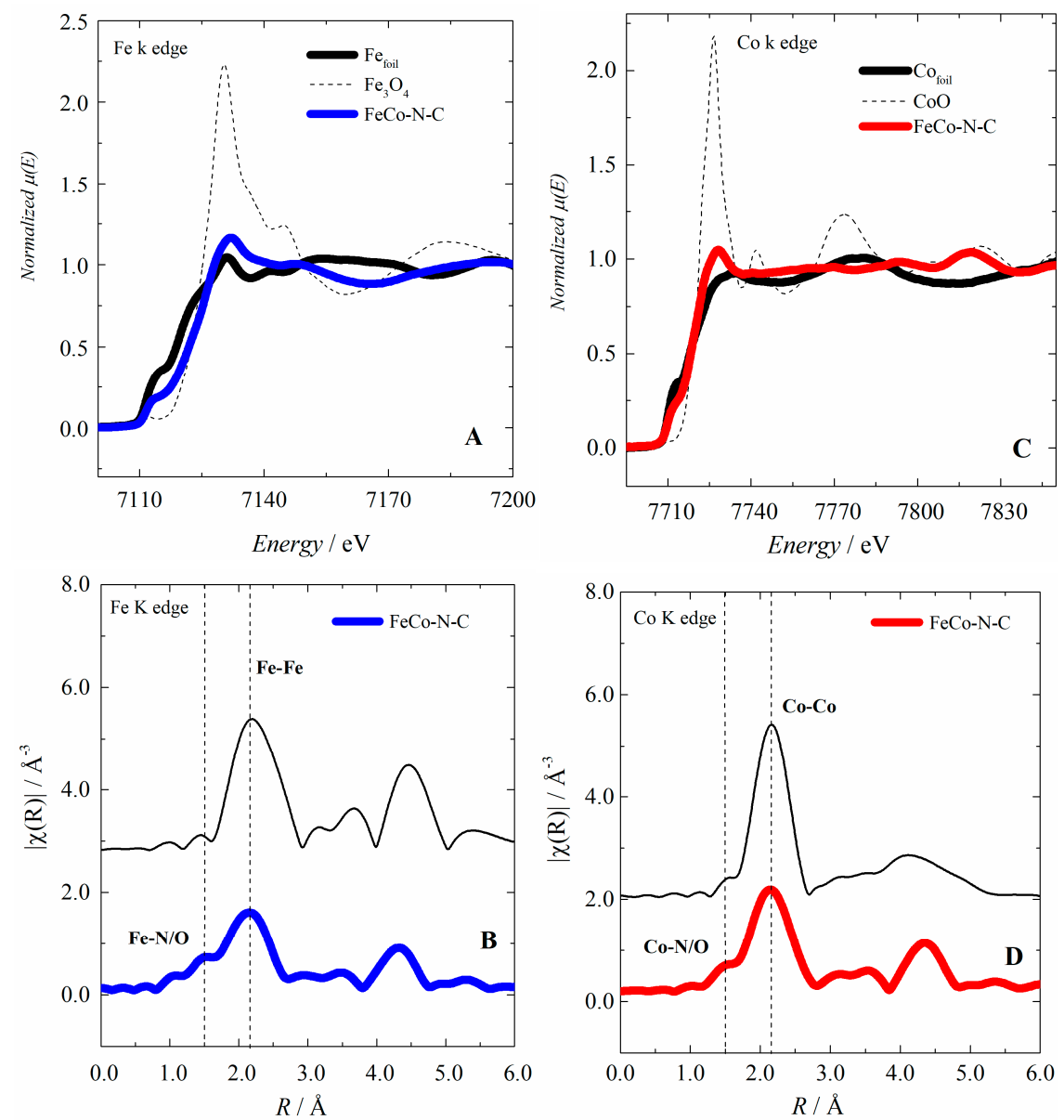

Figure 3. (A,C) XANES spectra and (B,D) Fourier transforms of the $\mathrm{K}^{2}$-weighted EXAFS oscillations measured at the Fe and Co edges for the FeCo-N-C sample. The reference spectra for iron and cobalt oxides and for iron and cobalt bulk metal (Fe and Co foils) were included for comparison. 
Table 1. The average percentage of elements investigated by EDX for the FeCo-N-C (as prepared) and Fe-Co-N-C AT (acid treated) samples.

\begin{tabular}{cccc}
\hline \multirow{2}{*}{ Electrocatalyst } & \multicolumn{3}{c}{ Composition (wt.\%) } \\
\cline { 2 - 4 } & Fe & Co & C \\
\hline FeCo-N-C & 5.0 & 4.6 & 90.4 \\
FeCo-N-C AT & 3.1 & 2.8 & 94.1 \\
\hline
\end{tabular}

\subsection{Investigation of the Electrocatalytic Activity for the ORR}

The comparison of the cyclic voltammetry curves obtained in $1.0 \mathrm{~mol} \mathrm{~L}^{-1} \mathrm{KOH}$ for Fe-N-C, $\mathrm{Co}-\mathrm{N}-\mathrm{C}, \mathrm{FeCo}-\mathrm{N}-\mathrm{C}$, and Vulcan is presented in Figure S4. The voltammograms show a typical capacitive behavior and similar magnitudes of current. This is coherent of their similar surface areas, as revealed by the BET characterization, of $189,211,174,178$, and $200 \mathrm{~m}^{2} \mathrm{~g}^{-1}$, for Fe-N-C, Co-N-C, FeCo-N-C, N-C, and Vulcan, respectively. So, it is noted that all surface areas are determined essentially by the Vulcan carbon area $\left(\sim 200 \mathrm{~m}^{2} \mathrm{~g}^{-1}\right)$, which is the carbon (and the support) for all considered materials. Additionally, it is observed a low-intensity "peak" currents centered at approximately $0.85 \mathrm{~V}$ for Fe-N-C and Co-N-C. This is associated with the demetallation (electro-dissolution) process, which is even more evident in an acid electrolyte (not shown here). However, on both electrolytes, these two peaks vanish after 2 voltammetric cycles, and the curves present as stable profile afterward. Probably, this metal dissolution may occur due to the carbon corrosion of some reactive carbon sites, which leads to the destruction of the neighboring metal-nitrogen species, releasing the metal ions, as evidenced in a previously published study [26].

The steady-state polarization curves obtained for the ORR on Fe-N-C, Co-N-C, and FeCo-N-C are presented in Figure 4A. The polarization curves for $\mathrm{Pt} / \mathrm{C}$ and for Vulcan were included for comparison. It is seen that $\mathrm{Co}-\mathrm{N}-\mathrm{C}, \mathrm{Fe}-\mathrm{N}-\mathrm{C}$, and FeCo-N-C are more active than Vulcan for the ORR [44]. Comparing the curves for $\mathrm{Co}-\mathrm{N}-\mathrm{C}$ and $\mathrm{Fe}-\mathrm{N}-\mathrm{C}$, it is observed that the material with cobalt has higher onset potential, while that with iron presents higher limiting current (higher number of electrons). This fact evidences that the nature of the metal in the electrocatalyst structure has a direct influence on the electrocatalytic activity. Although divergent results are found in the literature on which metal, iron or cobalt, is more active (probably due to different obtained structures), they agree on the statement that Fe and Co are the most active among different metals (compared to $\mathrm{Ni}, \mathrm{Mn}, \mathrm{Cu}$, etc.) in $\mathrm{M}-\mathrm{N}-\mathrm{C}$ electrocatalysts. Additionally, several studies show a synergistic effect between $\mathrm{Fe}$ and $\mathrm{Co}$, enhancing the activity for the ORR [14,45-47]. This fact can be observed in Figure 4A, which shows higher activity and higher limiting current for FeCo-N-C when compared to pure Fe-N-C or Co-N-C. Additionally, as noted in Figure 4A, the obtained ORR activity for FeCo-N-C is close to that of $\mathrm{Pt} / \mathrm{C}$, which is an important advance for the development of cathodes for fuel cells that operate with alkaline electrolytes. It is worth to note that the limiting current densities obtained for Fe-N-C, FeCo-N-C and Pt/C are very close to the predicted limiting current density by the Levich equation for a four-electron process in $1.0 \mathrm{~mol} \mathrm{~L}^{-1} \mathrm{KOH}$ (ca. $3.5 \mathrm{~mA} \mathrm{~cm}^{-2}$ ) [48].

The ORR curves in the region of high potentials $(0.6$ to $1.0 \mathrm{~V})$ obtained on the synthesized materials taken as blanks, such as $\mathrm{FeN}_{\mathrm{x}}, \mathrm{FeCo} @ \mathrm{C}, \mathrm{FeCoO}_{\mathrm{x}} / \mathrm{C}$, and N-C, are compared to those on FeCo-N-C and FeCo-N-C AT in Figure 4B. The ORR curves for Vulcan and $\mathrm{Pt} / \mathrm{C}$ were also included for comparison. The analysis of the figure reveals that $\mathrm{FeCo} @ \mathrm{C}$ and $\mathrm{Fe}_{x} \mathrm{~N}$ have no significant electrocatalytic activity since their onset potentials are equal to that of Vulcan. On the other hand, N-C shows an increase in the reaction potential onset and, thus, it evidences that the nitrogen-carbon bond forms an active site for the ORR. The curve for $\mathrm{FeCoO}_{x} / \mathrm{C}$ presents much higher onset potential in relation to Vulcan, and this shows that oxygen plays an important role, probably increasing the redox reactivity for the mediation process involved in the electron transfer for the ORR [44]. The most important aspect is that the material synthesized using imidazole as the nitrogen source $(\mathrm{FeCo}-\mathrm{N}-\mathrm{C})$ presented the highest electrocatalytic activity, giving indications that imidazole induces the formation of metal 
coordinate structures (M-N-C). Here, it is worth mentioning that the high activity observed for the FeCo-N-C material is not influenced by the co-existence of remaining Fe and / or Co oxides, since all metal oxides were leached out from the sample after the acid treatment (see the curve for FeCo-N-C (AT) in Figure 1B).

These results indicate that high electrocatalytic activity for the ORR is achieved only for the materials containing M-N-C species. This conclusion is not simple to delineate, because the synthesis of this type of structure leads to the parallel formation of similar species, as mentioned in the introduction section. It is evident, now, that carbon-encapsulated nanoparticles have the same activity of Vulcan, and the metal atoms in the core do not influence the electrocatalytic activity of the topmost layer of the graphitic carbon (at least for thick carbon layers, as in the case of the present study). The inclusion of a nitrogen-containing molecule as the nitrogen source, such as imidazole, producing the N-C species, resulted in a material with an increased activity in relation to pure carbon, but still much lower than that obtained for FeCo-N-C.
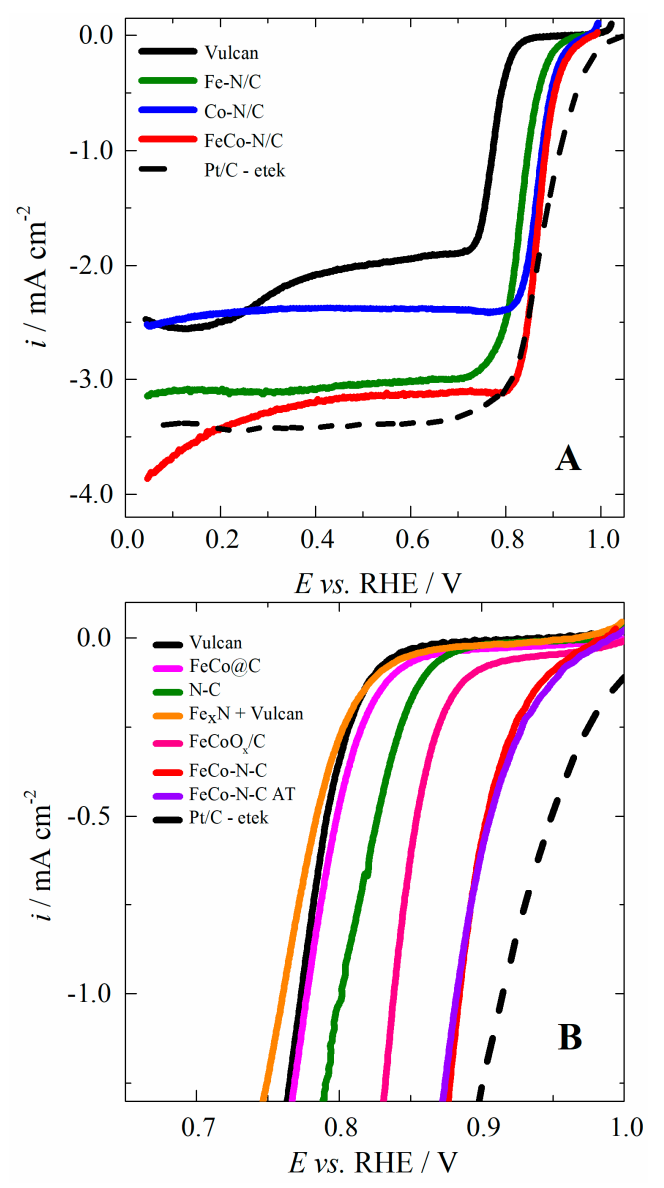

Figure 4. (A) Steady-state polarization curves obtained for the ORR in $\mathrm{O}_{2}$-saturated $1.0 \mathrm{~mol} \mathrm{~L}^{-1} \mathrm{KOH}$ electrolyte on Fe-N-C, Co-N-C, FeCo-N-C electrocatalysts, and (B) ORR at high potential domain on the synthesized structures taken as "blanks": FeN, FeCo@C, N-C, and for $\mathrm{FeCoO}_{\mathrm{x}} / \mathrm{C}$, compared to that on FeCo-N-C and FeCo-N-C AT. The ORR curves obtained on Vulcan and Pt/C were included for comparison. Scan rate: $5.0 \mathrm{mV} \mathrm{s}^{-1}$. Rotation rate: $1600 \mathrm{rpm}$.

\subsection{Formate Ions Tolerance of the FeCo-N-C Electrocatalyst}

As already mentioned, one of the main challenges involved in the commercialization of fuel cells is to develop electrocatalysts for ORR that are tolerant to the presence of the fuel in the cathode. This tolerance would be important due to the eventual crossover of the fuel through the membrane (that separate the anode and the cathode compartment), and it is mandatory in membraneless fuel 
cells (the case of the present study). Figure 5 shows the ORR curves for FeCo-N-C obtained in $\mathrm{O}_{2}$-saturated $1.0 \mathrm{~mol} \mathrm{~L}^{-1} \mathrm{KOH}$ containing potassium formate in different concentrations ( 0.001 to $0.1 \mathrm{~mol} \mathrm{~L}^{-1}$ ). It can be observed the same behavior of the curves in the absence and in the presence of this fuel, even at a concentration of $0.1 \mathrm{~mol} \mathrm{~L}^{-1}$. Figure $\mathrm{S} 5$ shows the comparison of the ORR curves obtained in $1.0 \mathrm{~mol} \mathrm{~L}^{-1}$ potassium formate electrolyte (no addition of $\mathrm{KOH}$ ) for $\mathrm{FeCo}-\mathrm{N}-\mathrm{C}$ and $\mathrm{Pt} / \mathrm{C}$. It is noteworthy that, contrary to the $\mathrm{FeCo}-\mathrm{N}-\mathrm{C}$ behavior, $\mathrm{Pt} / \mathrm{C}$ does not present reaction selectivity, and catalyzes the formate electro-oxidation and the ORR in parallel. Thus, in addition to its inherent high cost, $\mathrm{Pt} / \mathrm{C}$ is not feasible for application in cathodes of direct formate fuel cells, especially in the case of the membraneless fuel cell, which is the case of this study. On the other hand, besides being formed by abundant elements, $\mathrm{FeCo}-\mathrm{N}-\mathrm{C}$ is totally tolerant to the presence of formate ions.

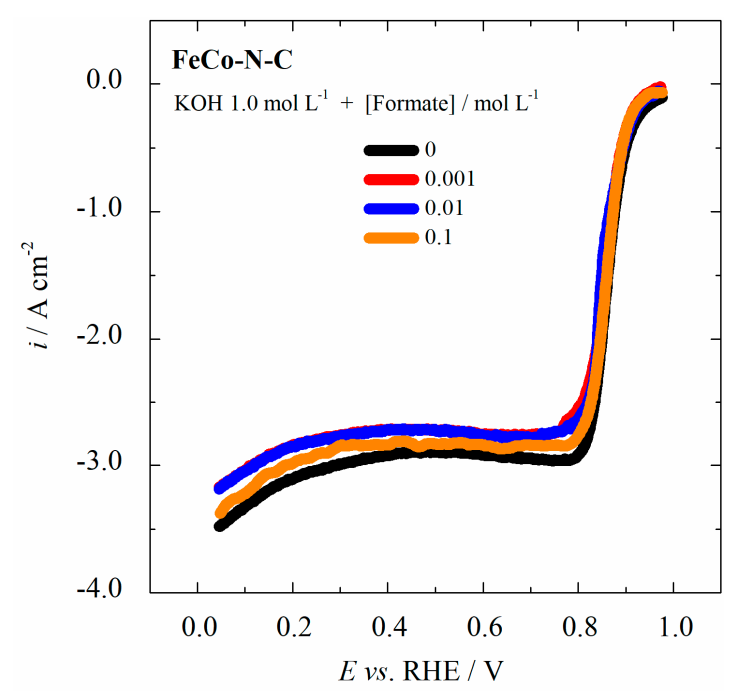

Figure 5. Steady-state polarization curves for the ORR on FeCo-N-C in $\mathrm{O}_{2}$-saturated $1.0 \mathrm{~mol} \mathrm{~L}^{-1} \mathrm{KOH}$ electrolyte, with different concentration of potassium formate, as indicated in the figure inset. Scan rate: $5.0 \mathrm{mV} \mathrm{s}^{-1}$. Rotation rate: $1600 \mathrm{rpm}$.

\subsection{Electrocatalytic Activity of FeCo-N-C for the ORR in Different Electrolytes}

As mentioned before, the $\mathrm{CO}_{2}$ molecules originated from the formate electro-oxidation (or even from the air-breathing cathode) will react with $\mathrm{OH}^{-}$forming $\mathrm{CO}_{3}{ }^{2-}$, and further reaction with $\mathrm{CO}_{2}$ will produce $\mathrm{HCO}_{3}{ }^{-}$[6]. Thus, the effect of the electrolyte nature and of the $\mathrm{pH}$ on the electrocatalytic activity for the ORR was investigated for the FeCo-N-C material. Figure 6 shows the potentiodynamic curves for the ORR in different electrolytes. (Note: the ORR curves are shown only at high potentials since the currents in the potential domain of diffusional control strongly depend on the solubility of $\mathrm{O}_{2}$ and on the viscosity of each solution). As can be noted, the ORR onset potential increases with the increase in the $\mathrm{pH}$ of the electrolyte: $\mathrm{KClO}_{4}(5.5)<$ phosphate buffer $(7.2)<\mathrm{HCOOK}(8.6) \approx$ $\mathrm{KHCO}_{3}(8.5)<\mathrm{K}_{2} \mathrm{CO}_{3}(12)<\mathrm{KOH}(14)$. Although there is still no consensus in the literature on the reason for such strong dependence, it is possible that the high kinetic at high $\mathrm{pH}$ values are related to the "facilitated kinetics mechanism" of the outer sphere in alkaline media, as proposed before [49]. It is noted that the ORR in $\mathrm{K}_{2} \mathrm{CO}_{3}$ has the closest half-wave potential of that found in $\mathrm{KOH}$, which should, therefore, be related to its high $\mathrm{pH}$ (ca. 12). This indicates that the operation on carbonate electrolyte can, in principle, be possible, with the ORR with rapid kinetics. For the electrolytes with near-neutral $\mathrm{pH}$, in addition to the slow kinetics, with low ORR half-wave potential, the operation of the fuel cell, even at moderate current densities, would result in a $\mathrm{pH}$ gradient between the cathode and the anode, causing a Nernstian potential loss [50]. Interestingly, the addition of small amounts of potassium carbonate in the potassium formate electrolyte is sufficient to increase the ORR half-wave potential on FeCo- $\mathrm{N}-\mathrm{C}$, approaching that obtained on $\mathrm{Pt} / \mathrm{C}$ in $\mathrm{KOH}$, as can be seen in the results presented in 
Figure 7. So, although the limiting current in the $\mathrm{HCOOK}+\mathrm{K}_{2} \mathrm{CO}_{3}$ electrolyte is lower than that on $\mathrm{KOH}$, due to the differences in oxygen solubility and electrolyte viscosity, the addition of $\mathrm{K}_{2} \mathrm{CO}_{3}$ has a beneficial effect due to the increased electrolyte $\mathrm{pH}$ when compared to pure HCOOK.

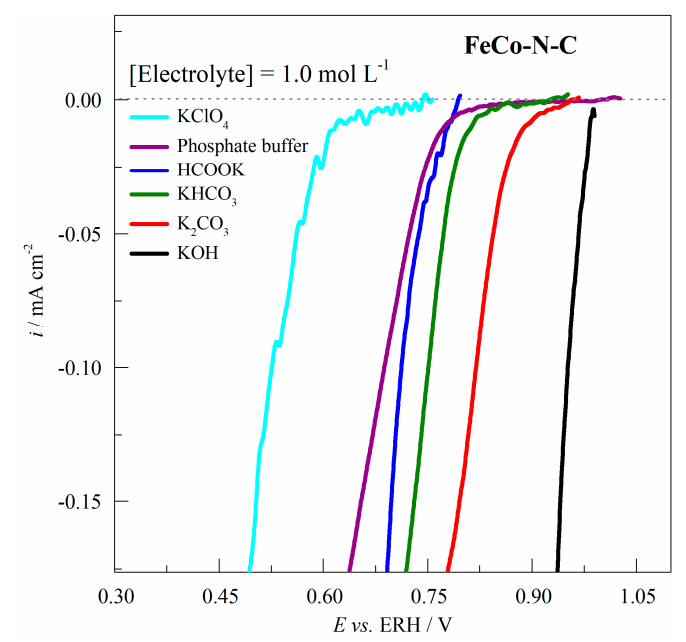

Figure 6. Steady-state polarization curves for the ORR on FeCo-N-C, showing the high potential domain, obtained in the different $\mathrm{O}_{2}$-saturated electrolytes, as indicated in the figure inset. Scan rate: $5.0 \mathrm{mV} \mathrm{s}^{-1}$. Rotation rate: $1600 \mathrm{rpm}$.

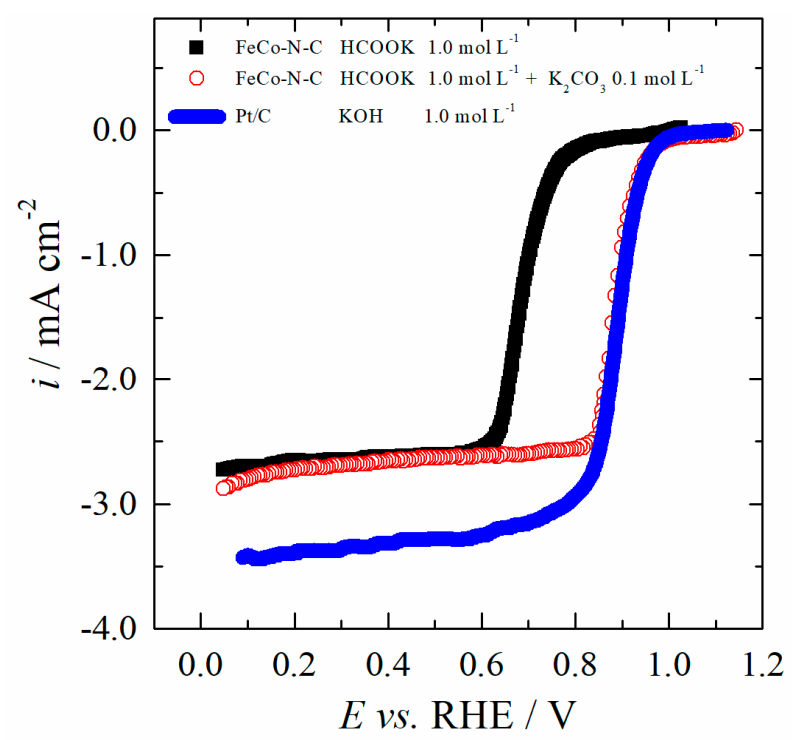

Figure 7. Steady-state polarization curves for the ORR on FeCo-N-C obtained in $\mathrm{O}_{2}$-saturated $1.0 \mathrm{~mol} \mathrm{~L}{ }^{-1} \mathrm{HCOOK}+0.1 \mathrm{~K}_{2} \mathrm{CO}_{3}$ (red cycles), and in $1.0 \mathrm{~mol} \mathrm{~L}^{-1} \mathrm{HCOOK}$ electrolyte (black squares). The curve for $\mathrm{Pt} / \mathrm{C}$ obtained in $1.0 \mathrm{~mol} \mathrm{~L}{ }^{-1} \mathrm{KOH}$ was included for comparison. Scan rate: $5.0 \mathrm{mV} \mathrm{s}^{-1}$. Rotation rate: $1600 \mathrm{rpm}$.

\subsection{Activity and Stability in Formate/Air Single Cells}

$\mathrm{FeCo}-\mathrm{N}-\mathrm{C}$ was also studied as the cathode electrocatalyst in passive air-breathing direct formate fuel cells, with different electrolytes. The polarization curves, obtained in electrolytes with potassium formate and in mixtures of potassium formate with potassium carbonate and potassium hydroxide, are presented in Figure 8A. The results reveal the following order of performance with the electrolyte: $\mathrm{HCOOK}<\mathrm{HCOOK}+\mathrm{K}_{2} \mathrm{CO}_{3}<\mathrm{HCOOK}+\mathrm{KOH}$. Interestingly, this is the same order of activity encountered for the ORR in the half-cell measurements. The resulting magnitudes of power densities 
were 2.0, 10.5 and $15.5 \mathrm{~mW} \mathrm{~cm}^{-2}$, respectively, following the trend of increasing electrolyte $\mathrm{pH}$. The cell with pure potassium formate as electrolyte showed the lowest power density, and this is a result of the Nernst potential loss due to the $\mathrm{pH}$ gradient that is established when current is drained from the cell (protons build up in the anode and hydroxide ions build up near the cathode). Figure $8 \mathrm{~B}$ shows the behavior of the galvanostatic curves obtained at $3.0 \mathrm{~mA} \mathrm{~cm}^{-2}$ in the three different electrolytes. The highest stability is observed for the cell with the $\mathrm{HCOOK}+\mathrm{KOH}$, followed by the cell with $\mathrm{KCOOH}$ $+\mathrm{K}_{2} \mathrm{CO}_{3}$. The apparent instability observed in pure HCOOK may also be ascribed to the $\mathrm{pH}$ gradient, which is intensified as a function of the time. Figure $\mathrm{S} 6$ shows the result of potentiostatic measurement, at $0.5 \mathrm{~V}$, for the DFFC filled with $2.0 \mathrm{~mol} \mathrm{~L}-1$ HCOOK $+2.0 \mathrm{~mol} \mathrm{~L}^{-1} \mathrm{~K}_{2} \mathrm{CO}_{3}$ electrolyte. It can be seen high current stability during $120 \mathrm{~h}$, indicating that both cathode and anode electrocatalysts do not suffer any kind of deactivation or activity loss. Although not shown here, it is worth to mention that this fuel cell also powered a laboratory wall clock, uninterruptedly, for six months, at $0.5 \mathrm{~mA} \mathrm{~cm}{ }^{-2}$.
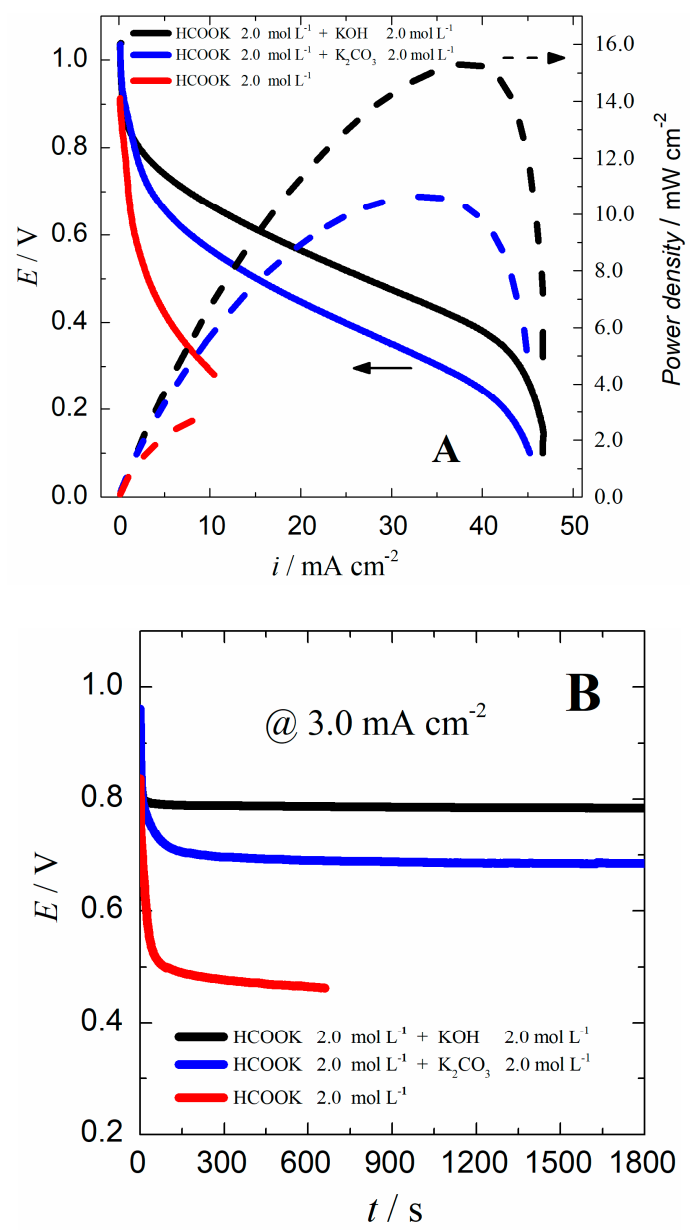

Figure 8. (A) Potentiodynamic curves and the corresponding power densities obtained in the passive air-breathing direct formate fuel cell and; (B) Chronopotentiometric curves obtained at $3.0 \mathrm{~mA} \mathrm{~cm}^{-2}$ in different electrolytes, as indicated in the figure inset. Cathode: FeCo-N-C; Anode: PdPt/C 4:1. All measurements were recorded at $25^{\circ} \mathrm{C}$.

Therefore, these results show that direct formate fuel cells, with air cathodes, and with the natural diffusion of formate, especially those with cathodes with electrocatalysts formed by abundant elements, can be a viable alternative as energy converters. For this scenario, they would be interesting for applications as power generators in remote locations or in energy backup systems, where power is required reliably and uninterruptedly, such as in hospitals, laboratories, and data centers. 


\section{Experimental Section}

\subsection{Reactants and Materials}

Iron nitrate $\left(\mathrm{Fe}\left(\mathrm{NO}_{3}\right)_{3} \cdot 9 \mathrm{H}_{2} \mathrm{O}\right)$, cobalt nitrate $\left(\mathrm{Co}\left(\mathrm{NO}_{3}\right)_{2} \cdot 6 \mathrm{H}_{2} \mathrm{O}\right)$, imidazole $\left(\mathrm{C}_{3} \mathrm{H}_{4} \mathrm{~N}_{2}\right)$, ethanol $\left(\mathrm{C}_{2} \mathrm{H}_{5} \mathrm{OH}\right)$, isopropanol $\left(\mathrm{C}_{3} \mathrm{H}_{7} \mathrm{OH}\right)$, potassium $(\mathrm{KOH})$ and sodium hydroxides $(\mathrm{NaOH})$, sulfuric acid $\left(\mathrm{H}_{2} \mathrm{SO}_{4}\right)$, potassium formate $(\mathrm{HCOOK})$, potassium bicarbonate $\left(\mathrm{KHCO}_{3}\right)$, potassium carbonate $\left(\mathrm{K}_{2} \mathrm{CO}_{3}\right)$, sodium carbonate $\left(\mathrm{Na}_{2} \mathrm{CO}_{3}\right)$, dipotassium phosphate $\left(\mathrm{K}_{2} \mathrm{HPO}_{4}\right)$, monopotassium phosphate $\left(\mathrm{H}_{2} \mathrm{PO}_{4}\right)$, dihydrogen phosphate $\left(\mathrm{H}_{3} \mathrm{PO}_{4}\right)$, potassium perchlorate $\left(\mathrm{KClO}_{4}\right)$, palladium $\left(\mathrm{PdCl}_{2}\right)$ chloride, sodium citrate $\left(\mathrm{Na}_{3} \mathrm{C}_{6} \mathrm{H}_{5} \mathrm{O}_{7}\right)$, sodium borohydride $\left(\mathrm{NaBH}_{4}\right)$, hexachloroplatinic acid hexahydrate $\left(\mathrm{H}_{2} \mathrm{PtCl}_{6} \cdot 6 \mathrm{H}_{2} \mathrm{O}\right)$ were acquired commercially from Sigma-Aldrich (St. Louis, MO, USA). Vulcan carbon $\mathrm{XC}-72 \mathrm{R}$ was purchased from Cabot Corp.

\subsection{Electrocatalysts under the Focus of this Study-Fe-N-C, Co-N-C e FeCo-N-C}

Nitrogen-coordinated Fe and/or Co atoms inserted on carbon matrix, represented by Fe-N-C, $\mathrm{Co}-\mathrm{N}-\mathrm{C}$, and FeCo-N-C (which are central in this study), were synthesized with $10 \mathrm{wt} . \%$ metal content relative to the amount of carbon ( $5 \%$ for each metal in the bimetallic material), following a previously proposed synthesis procedure [27] (the metal loading of $10 \mathrm{wt} . \%$ was intentionally chosen to induce the formation of the secondary species, such as encapsulated nanoparticles, $\mathrm{N}$-doped carbon, and metal nitrides, in addition to the desired product, $\mathrm{M}-\mathrm{N}-\mathrm{C}$ ). In the preparation of the M-N-C materials, the metal precursors ( $311 \mathrm{mg}$ of the iron nitrate, $197 \mathrm{mg}$ of cobalt nitrate, and $155 \mathrm{mg}$ and $98 \mathrm{mg}$ of iron and cobalt nitrates for Fe-N-C, Co-N-C e FeCo-N-C, respectively) were dissolved in $50 \mathrm{~mL}$ of ethanol. Then, $160 \mathrm{mg}$ of imidazole was added, and the solution was kept under vigorous magnetic stirring at $60{ }^{\circ} \mathrm{C}$, for $1 \mathrm{~h}$. After this step, $200 \mathrm{mg}$ of Vulcan carbon was added, the suspension was maintained in an ultrasonic bath for $10 \mathrm{~min}$, and this was followed by magnetic stirring for $4 \mathrm{~h}$. In the next step, ethanol was evaporated at $70{ }^{\circ} \mathrm{C}$, under stirring, for the impregnation of the metal nitrates and of the imidazole molecules on the carbon powder, until becoming a dense ink, which was subsequently kept drying in an oven at $80^{\circ} \mathrm{C}$ overnight (for the total evaporation of the solvent and eventual water residue). The resulting powder was subjected to a thermal treatment (pyrolysis) at $700{ }^{\circ} \mathrm{C}$ under $\mathrm{N}_{2}$ atmosphere for $10 \mathrm{~h}$. After this, the material was treated in sulfuric acid $\left(0.5 \mathrm{~mol} \mathrm{~L}^{-1}\right)$ at $60^{\circ} \mathrm{C}$ for $48 \mathrm{~h}$, under stirring, for the dissolution of eventual unprotected or partially encapsulated metallic nanoparticles, and/or metal oxides, (originated from metal atoms that were not incorporated into the desired coordination structure). Thereafter, the powder was filtered and washed several times with deionized water and placed to dry at $80{ }^{\circ} \mathrm{C}$ in oven. Finally, the powder was treated again in $\mathrm{N}_{2}$ atmosphere at $700{ }^{\circ} \mathrm{C}$, for $10 \mathrm{~h}$.

\subsection{Materials Synthesized for Comparison: $F e C o O_{x} / \mathrm{C}, \mathrm{FeCo@C}, \mathrm{Fe}_{x} \mathrm{~N}$ and N-C}

The nanostructures that are commonly formed during the pyrolysis step for the M-N-C synthesis were, here, deliberately synthesized aiming at isolating their electrocatalytic activities for the ORR (the nanostructures are disposed in increasing order of structure complexity): Iron and cobalt oxides supported on carbon, represented by $\mathrm{FeCoO}_{x} / \mathrm{C}$; iron nitride, represented by $\mathrm{Fe}_{\mathrm{x}} \mathrm{N}$; carbon-encapsulated iron and cobalt nanoparticles, represented by FeCo@C, and nitrogen-doped carbon, represented as N-C. For the preparation of the $\mathrm{FeCoO}_{x} / \mathrm{C}$ nanoparticles, the as-prepared FeCo-N-C electrocatalyst was brought to thermal treatment in the $\mathrm{O}_{2}$ atmosphere at $300{ }^{\circ} \mathrm{C}$, for $3 \mathrm{~h}$. FeCo@C were synthesized with 10 wt.\% of $\mathrm{Co}+\mathrm{Fe}$, relative to the amount of carbon (5\% for each metal) starting from the impregnation of the iron and cobalt nitrates on Vulcan carbon powder, following the same initial steps for the synthesis of the M-N-C materials, but without imidazole. After this, resulting powder was subjected to heat treatment at $1050^{\circ} \mathrm{C}$ under Ar atmosphere for $1 \mathrm{~h}$. $\mathrm{Fe}_{\mathrm{x}} \mathrm{N}$ was obtained from the heat treatment of $400 \mathrm{mg}$ of $\mathrm{Fe}\left(\mathrm{NO}_{3}\right)_{3} \cdot 9 \mathrm{H}_{2} \mathrm{O}$ at $400{ }^{\circ} \mathrm{C}$, in air, during $3 \mathrm{~h}$, (producing iron oxide), followed by treatment in the $\mathrm{NH}_{3}$ atmosphere, at $950{ }^{\circ} \mathrm{C}$, during $3 \mathrm{~h}$. For a more meaningful comparison, since most of the materials were synthesized using Vulcan carbon as the carbon source 
(and as the conducting support), the as-received Vulcan carbon was treated in argon atmosphere at $1050{ }^{\circ} \mathrm{C}$, for $1 \mathrm{~h}$, and the resulting material is represented hereafter as Vulcan. This material was also doped with nitrogen using imidazole as a nitrogen source, N-C. For its synthesis, imidazole was dissolved in a Vulcan carbon suspension in ethanol, and this was followed by ethanol evaporation at $60{ }^{\circ} \mathrm{C}$ under magnetic stirring. Subsequently, the impregnated carbon powder was treated in an $\mathrm{N}_{2}$ atmosphere at $700{ }^{\circ} \mathrm{C}$ for $10 \mathrm{~h}$.

\subsection{Synthesis of the Anode Electrocatalyst for the Single Cell Measurements}

The anode electrocatalyst for the single cell experiments was carbon-supported palladium-platinum nanoparticles, $\mathrm{PdPt} / \mathrm{C}$, with $20 \mathrm{wt} . \%$ of metal, and with atomic ratio of 4:1 (Pd:Pt), according to the best results previously published by Vielstich et al. [2,51]. For the synthesis, $26.60 \mathrm{mg}$ of $\mathrm{PdCl}_{2}$ and $10.62 \mathrm{mg}$ of $\mathrm{H}_{2} \mathrm{PtCl}_{6} \cdot 6 \mathrm{H}_{2} \mathrm{O}$ were dissolved in water in the presence of $200 \mathrm{mg}$ of $\mathrm{Na}_{3} \mathrm{C}_{6} \mathrm{H}_{5} \mathrm{O}_{7}$ (used as a stabilizer, which prevents or limits the growth of the nanoparticles). A solution of $0.5 \mathrm{~mol} \mathrm{~L}^{-1} \mathrm{NaBH}_{4}$ and $0.1 \mathrm{~mol} \mathrm{~L}^{-1} \mathrm{NaOH}$ was, then, rapidly added, leading to the reduction of the metal ions, with the consequent formation of nanoparticles in colloidal suspension. Immediately after reduction, a suspension of Vulcan carbon powder, previously prepared in a water-isopropanol (3:1 in volume) mixture, was added to the reaction vessel, and this was maintained under magnetic stirring for $24 \mathrm{~h}$ in order to anchor the nanoparticles on the carbon powder. Then, the suspension was vacuum-filtered, copiously washed with ultrapure water, and kept in an oven at $80{ }^{\circ} \mathrm{C}$, for $24 \mathrm{~h}[52,53]$.

\subsection{Electrocatalyst Characterization}

The crystalline structures and/or phases of the synthesized electrocatalysts were determined by X-ray diffraction (XRD) using a RIGAKU diffractometer model ULTIMA IV (RIGAKU, Tokyo, Japan). The diffractograms were obtained in the reflection mode, in range of 10 to $100^{\circ}(2 \theta)$, with a scan rate of $1.0^{\circ} / \mathrm{min}$, and with a step size of $0.05^{\circ}$, using the $\mathrm{Cu} \mathrm{K} \mathrm{K}_{\alpha}$ as the incident radiation. The samples were analyzed using the standard crystal data sheets of the EVA program (Brucker). The compositions of the electrocatalysts were estimated via Energy-Dispersive X-Ray Spectroscopy (EDX), in an LEO 440 SEM-EDX (Leica-Zeiss, DSM-960, Oberkochen, Germany) scanning electron microscope equipped with a microanalyzer (Link Analytical QX 2000, Oberkochen, Germany). For the analysis, the samples were prepared as pressed powder pellets.

The morphological analyzes were performed by Transmission Electron Microscopy (TEM)) in a JEOL JEM 2100F (JEOL, Tokyo, Japan) microscopy, operating with a voltage of $200 \mathrm{kV}$. The samples were prepared with the dispersion of the electrocatalysts in isopropyl alcohol under an ultrasonic bath for $10 \mathrm{~min}$. Subsequently, the material was deposited (dip-casted) on a copper grid (3.0 $\mathrm{mm}$ in diameter and 300 mesh) covered by carbon fibers. After deposition, the sample holders containing the materials were left in a desiccator under vacuum, for $12 \mathrm{~h}$. The oxidation state and species present in the first coordination shell of Fe and $\mathrm{Co}$ in the FeCo-N-C electrocatalyst were determined by X-ray Absorption Spectroscopy (XAS) (XAFS-2 beamline, Brazilian Synchrotron Light Laboratory, LNLS) in the XANES (X-ray Absorption Near Edge Structure) EXAFS (Extended X-ray Absorption Fine Structure) regions. The spectra were obtained at the edges of Fe at $7112 \mathrm{eV}$, and Co at $7709 \mathrm{eV}$. The samples were formed by Nafion ${ }^{\circledR}$-agglutinated rectangular-shaped pellets ( $30.0 \mathrm{wt} . \%$ of Nafion), obtained by pressing the powders with 1.0 ton of pressure. The EXAFS oscillations were analyzed in the Athena and Artemis software and were adjusted using standard procedures in R space using $\mathrm{K}^{2}$ weighted Fourier transform.

\subsection{Electrochemical Measurements}

The half-cell measurements were conducted in a conventional electrochemical cell with three electrodes. A gold plate and an $\mathrm{Ag} / \mathrm{AgCl} / \mathrm{Cl}^{-}$were used as counter and reference electrodes, respectively. The working electrodes were formed by an ultrathin layer $(10-50 \mu \mathrm{m})$ of the electrocatalyst under investigation, deposited on the surface of a glassy carbon rotating disk electrode $\left(0.196 \mathrm{~cm}^{2}\right.$, 
Pine Inst.). The electrocatalyst layers were prepared by depositing $25 \mu \mathrm{L}$ aliquots of the electrocatalyst suspensions, prepared from $5.0 \mathrm{mg}$ of the electrocatalyst and $50 \mu \mathrm{L}$ of a Nafion solution ( $5.0 \mathrm{wt} . \%)$ in $1.0 \mathrm{~mL}$ isopropanol [54]. All electrolyte solutions were prepared using ultrapure water obtained in a Milli-Q system (Millipore, Burlington, MA, USA).

The cyclic voltammetry experiments were performed at $50.0 \mathrm{mV} \mathrm{s}^{-1}$, under stagnant condition, with the electrolytes saturated with argon. The experiments for ORR were obtained by means of steady-state polarization curves at $5.0 \mathrm{mV} \mathrm{s}^{-1}$, with $\mathrm{O}_{2}$-saturated electrolytes. All measurements were conducted at $25^{\circ} \mathrm{C}$, and all potentials presented in this work were corrected for the different electrolyte $\mathrm{pHs}$ and presented versus the Reversible Hydrogen Electrode (RHE). All electrochemical measurements were performed using an AUTOLAB (PGSTAT30) potentiostat. The ORR experiments aiming to investigate the tolerance of the electrocatalysts to formate ions were carried out in the presence of potassium formate in different concentrations, from 0.001 to $0.1 \mathrm{~mol} \mathrm{~L}^{-1}$, added to the $1.0 \mathrm{~mol} \mathrm{~L}^{-1} \mathrm{KOH}$ electrolyte.

\subsection{Measurements in Single Cells}

The activity and stability of FeCo-N-C were tested in a fuel cell. This consisted of a Passive Air-Breathing Direct Formate Fuel Cell, constructed based on previous publications [2,51]. In this cell, the fuel and the electrolyte fill the cell volume, with the anode fully immersed in the electrolyte, and with one of the sides of the cathode exposed to the air via a gas diffusion layer. The schematics of the Passive Air-breading Direct Formate Fuel Cell is presented in the Figure S1. The anode was constructed from a disk-shaped nickel screen $\left(18\right.$ mesh), with $17.34 \mathrm{~cm}^{2}$, that has the role of the current collector. Teflon-agglutinated Vulcan carbon powder, prepared by impregnating a suspension of Teflon (5.0\% wt. in water + surfactant (Triton X-100)) on carbon (stirring followed by solvent evaporation), was rolled on both sides of this electrode and pressed at 2.0 ton $\mathrm{cm}^{-2}$ [55]. Then, a suspension containing $5.0 \mathrm{mg} \mathrm{mL}^{-1}$ of the PdPt/C electrocatalyst in isopropanol and containing $5.0 \mathrm{wt} . \%$ of Teflon (in relation to the total mass of electrocatalyst), was deposited on one side of the anode using a brush. The total metal loading $(\mathrm{Pd}+\mathrm{Pt})$ deposited on the anode was $0.5 \mathrm{mg} \mathrm{cm}^{-2}$. The cathode was formed by a nickel screen of the same mesh and diameter, in contact with a gas diffusion electrode (GDE). The GDE was prepared by applying the Teflon-agglutinated carbon to a carbon cloth (PWB-3, Stackpole) by the vacuum filtration procedure, followed by heat treatment at $280{ }^{\circ} \mathrm{C}$ in air, for $30 \mathrm{~min}$, for the decomposition of the stabilizer (Triton X-100), and at $330{ }^{\circ} \mathrm{C}$ in air, for $30 \mathrm{~min}$, for sintering and consequent formation of micro-channels on carbon (for gas transport in GDE) [56]. The nickel screen and the GDE were placed together by pressing these two components with Teflon-agglutinated carbon powder in between, using 2.0 ton $\mathrm{cm}^{-2}$ of pressure (the Teflon-agglutinated carbon permits to bind these two components, as it occupies the pores of the GDE and the spaces of the nickel screen). Finally, a suspension of FeCo-N-C was prepared with $5.0 \mathrm{mg} \mathrm{mL}^{-1}$ of the electrocatalyst isopropanol, and containing $5.0 \mathrm{wt} . \%$ of Teflon. This was followed by the deposition on the as-prepared electrode using a brush, resulting in an electrocatalyst loading of $1.0 \mathrm{mg} \mathrm{cm}^{-2}$.

The single cell measurements were conducted using three different electrolytes: $2.0 \mathrm{~mol} \mathrm{~L}^{-1}$ $\mathrm{HCOOK}+2.0 \mathrm{~mol} \mathrm{~L}-1 \mathrm{KOH} ; 2.0 \mathrm{~mol} \mathrm{~L}{ }^{-1} \mathrm{HCOOK}+2.0 \mathrm{~mol} \mathrm{~L}^{-1} \mathrm{~K}_{2} \mathrm{CO}_{3}$; and $2.0 \mathrm{~mol} \mathrm{~L}^{-1} \mathrm{HCOOK}$. Potentiodynamic experiments were recorded between the open circuit potential to $0.1 \mathrm{~V}$ (or to $0.25 \mathrm{~V}$, depending on the electrolyte). Galvanostatic and potentiostatic measurements, conducted at $3.0 \mathrm{~mA} \mathrm{~cm}^{-2}$ and $0.5 \mathrm{~V}$, respectively, were carried out to evaluate the short and medium-term stability of the DFFC.

\section{Conclusions}

The results obtained in this study showed that carbon-encapsulated iron-cobalt nanoparticles, and carbon-supported metal nitrides, do not present significant activity for the ORR in alkaline media, showing the same half-wave potential of Vulcan. On the other hand, N-doped Vulcan showed an increased activity, evidencing that nitrogen has a fundamental importance in the active site. 
The insertion of oxygen, via thermal treatment in air, forming carbon-supported nanostructured FeCo oxides, produced an increase in the activity for the ORR, probably due to the higher Fe and Co redox reactivity of those oxides, which mediate the electron transfer to oxygen. EXAFS measurements revealed that the addition of a nitrogen precursor during the synthesis resulted in the formation of $\mathrm{M}-\mathrm{N}-\mathrm{C}$ structures inserted in a carbon matrix (FeCo-N-C material), and the electrocatalytic activity for the ORR approached that of the state-of-the-art $\mathrm{Pt} / \mathrm{C}$. Additionally, $\mathrm{FeCo}-\mathrm{N}-\mathrm{C}$ was very tolerant to the presence of formate ions in the electrolyte. Measurements in single cells with the natural diffusion of formate, and with air-breathing cathodes, showed peak power densities of 15.5 and $10.5 \mathrm{~mW} \mathrm{~cm}^{-2}$ using hydroxide and carbonate-based electrolytes, respectively, and high stability during long-term operation.

Supplementary Materials: The following are available online at http:/ /www.mdpi.com/2073-4344/8/8/320/s1, Additional TEM data, ORR polarization curves, and single cell measurements. Figure S1. Schematics of the Passive Air-breading Direct Formate Fuel Cell utilized for testing the electrocatalytic activity and stability of the synthesized FeCo-N-C electrocatalyst. The anode is entirely immersed in the anolyte, and the fuel is transported to the electrode surface via natural diffusion. The cathode is opened to the air using a gas diffusion electrode. Figure S2. X-ray diffractograms obtained for the synthesized materials utilized as "blanks": $\mathrm{FeCoOx} / \mathrm{C}, \mathrm{FeCo} @ \mathrm{C}$, FexN, N-C. The attribution of each peak is included in the figure inset. Figure S3. Transmission Electron Microscopy image of the carbon-encapsulated iron-cobalt nanoparticle, FeCo@C, prepared via thermal treatment at $1050^{\circ} \mathrm{C}$ in Ar atmosphere. The inset shows the graphite carbon layer that entirely encapsulates the metallic nanoparticle. Figure S4. Cyclic voltammograms for Fe-N-C, Co-N-C, and FeCo-N-C electrocatalysts obtained in Ar-saturated $1.0 \mathrm{~mol} \mathrm{~L}^{-1} \mathrm{KOH}$ electrolyte. The voltammogram for Vulcan was included for comparison. Scan rate: $50 \mathrm{mV} \mathrm{s}^{-1}$. Figure S5. Polarization curves for the ORR on FeCo-N-C and $\mathrm{Pt} / \mathrm{C}$ in $\mathrm{O}_{2}$-saturated $1.0 \mathrm{~mol} \mathrm{~L}-1$ HCOOK electrolyte. The curves show the selectivity for the ORR (or tolerance to the presence of formate) of the Fe-Co-N-C electrocatalyst, and the poor selectivity of Pt/C. Scan rate: $5.0 \mathrm{mVs}^{-1}$. Rotation rate: $1600 \mathrm{rpm}$. Figure S6. Durability test obtained in the passive air-breathing direct formate fuel cell conducted via potentiostatic measurements at $0.5 \mathrm{~V}$ in $2.0 \mathrm{~mol} \mathrm{~L}{ }^{-1} \mathrm{KCOOH}+2.0 \mathrm{~mol} \mathrm{~L}^{-1} \mathrm{~K}_{2} \mathrm{CO}_{3}$ electrolyte, during $120 \mathrm{~h}$. Cathode: FeCo-N-C; Anode: $\mathrm{PdPt} / \mathrm{C} 4: 1$. The measurement was recorded at $25^{\circ} \mathrm{C}$.

Author Contributions: F.E.R.O. performed the experiments; N.A.G. and F.H.B.L. analyzed the data; N.A.G. and F.H.B.L. wrote the paper.

Acknowledgments: The authors gratefully acknowledge financial support from FAPESP (Fundação de Amparo à Pesquisa do Estado de São Paulo, F.H.B.L. grant N ${ }^{\circ}$. 2016/13323-0 and 2013/16930-7 and N.A.G. grant $\mathrm{N}^{\circ}$. 2016/06197-9), CNPq (Conselho Nacional de Desenvolvimento Científico e Tecnológico, F.H.B.L. grant $\mathrm{N}^{\circ}$. 306469/2016-2), CAPES (Coordenação de Aperfeiçoamento de Pessoal de Nível Superior, F.E.R.O. grant $\mathrm{N}^{\mathrm{o}} .1255731$ ), and the Brazilian Synchrotron Light Laboratory (LNLS, XAFS2 beamline) for assisting with the XAS experiments.

Conflicts of Interest: The authors declare no conflict of interest.

\section{References}

1. Ghoniem, A.F. Needs, resources and climate change: Clean and efficient conversion technologies. Prog. Energy Combust. Sci. 2011, 37, 15-51. [CrossRef]

2. Taberner, P.; Heitbaum, J.; Vielstich, W. The influence of the electrolyte composition on the formate oxidation in alkaline formate-air fuel cells. Electrochim. Acta 1976, 21, 439-440. [CrossRef]

3. Jiang, J.; Wieckowski, A. Prospective direct formate fuel cell. Electrochem. Commun. 2012, 18, 41-43. [CrossRef]

4. Vo, T.; Purohit, K.; Nguyen, C.; Biggs, B.; Mayoral, S.; Haan, J.L. Formate: An Energy Storage and Transport Bridge between Carbon Dioxide and a Formate Fuel Cell in a Single Device. ChemSusChem 2015, 8, 3853-3858. [CrossRef] [PubMed]

5. Sandstede, G.; Cairns, E.J;; Bagotsky, V.S.; Wiesener, K. History of Low Temperature Fuel Cells. In Handbook of Fuel Cells; John Wiley \& Sons: Chichester, UK, 2010; ISBN 9780470974001.

6. Nishimura, K.; Machida, K.; Enyo, M. Electrooxidation of formate and formaldehyde on electrodes of alloys between Pd and Group IB metals in alkaline media Part II. The possibility of complete oxidation of formaldehyde in weak alkali. J. Electroanal. Chem. Interfacial Electrochem. 1988, 251, 117-125. [CrossRef]

7. Beden, B.; Lamy, C.; Leger, J.M. Electrocatalytic Activity of Noble Metals for the Oxidation of Formate in Neutral Medium. J. Electroanal. Chem. 1979, 101, 127-131. [CrossRef] 
8. John, J.; Wang, H.; Rus, E.D.; Abruña, H.D. Mechanistic studies of formate oxidation on platinum in alkaline medium. J. Phys. Chem. C 2012, 116, 5810-5820. [CrossRef]

9. Perales-Rondón, J.V.; Brimaud, S.; Solla-Gullón, J.; Herrero, E.; Jürgen Behm, R.; Feliu, J.M. Further Insights into the Formic Acid Oxidation Mechanism on Platinum: PH and Anion Adsorption Effects. Electrochim. Acta 2015, 180, 479-485. [CrossRef]

10. Joo, J.; Uchida, T.; Cuesta, A.; Koper, M.T.M.; Osawa, M. Importance of Acid-Base Equilibrium in Electrocatalytic Oxidation of Formic Acid on Platinum. J. Am. Chem. Soc. 2013, 135, 9991-9994. [CrossRef] [PubMed]

11. Banham, D.; Ye, S.; Pei, K.; Ozaki, J.I.; Kishimoto, T.; Imashiro, Y. A review of the stability and durability of non-precious metal catalysts for the oxygen reduction reaction in proton exchange membrane fuel cells. J. Power Sources 2015, 285, 334-348. [CrossRef]

12. Jasinski, R. A new fuel cell cathode catalyst. Nature 1964, 201, 1212-1213. [CrossRef]

13. Unni, S.M.; Devulapally, S.; Karjule, N.; Kurungot, S. Graphene enriched with pyrrolic coordination of the doped nitrogen as an efficient metal-free electrocatalyst for oxygen reduction. J. Mater. Chem. 2012, 22, 23506-23513. [CrossRef]

14. Wu, G.; More, K.L.; Johnston, C.M.; Zelenay, P. High-performance electrocatalysts for oxygen reduction derived from polyaniline, iron, and cobalt. Science 2011, 332, 443-447. [CrossRef] [PubMed]

15. Van Veen, J.A.R.; Colijn, H.A.; van Baar, J.F. On the effect of a heat treatment on the structure of carbon-supported metalloporphyrins and phthalocyanines. Electrochim. Acta 1988, 33, 801-804. [CrossRef]

16. Mamtani, K.; Singh, D.; Tian, J.; Millet, J.-M.M.; Miller, J.T.; Co, A.C.; Ozkan, U.S. Evolution of N-Coordinated Iron-Carbon (FeNC) Catalysts and Their Oxygen Reduction (ORR) Performance in Acidic Media at Various Stages of Catalyst Synthesis: An Attempt at Benchmarking. Catal. Lett. 2016, 146, 1749-1770. [CrossRef]

17. Bezerra, C.W.B.; Zhang, L.; Lee, K.; Liu, H.; Marques, A.L.B.; Marques, E.P.; Wang, H.; Zhang, J. A review of Fe-N/C and Co-N/C catalysts for the oxygen reduction reaction. Electrochim. Acta 2008, 53, 4937-4951. [CrossRef]

18. Wu, G.; Santandreu, A.; Kellogg, W.; Gupta, S.; Ogoke, O.; Zhang, H.; Wang, H.L.; Dai, L. Carbon nanocomposite catalysts for oxygen reduction and evolution reactions: From nitrogen doping to transition-metal addition. Nano Energy 2016, 29, 83-110. [CrossRef]

19. Sun, M.; Liu, H.; Qu, J.; Li, J. Earth-Rich Transition Metal Phosphide for Energy Conversion and Storage. Adv. Energy Mater. 2016, 6, 1-34. [CrossRef]

20. Sun, M.; Davenport, D.; Liu, H.; Qu, J.; Elimelech, M.; Li, J. Highly efficient and sustainable non-precious-metal Fe-N-C electrocatalysts for the oxygen reduction reaction. J. Mater. Chem. A 2018, 6, 2527-2539. [CrossRef]

21. Liu, W.; Zhang, L.; Liu, X.; Liu, X.; Yang, X.; Miao, S.; Wang, W.; Wang, A.; Zhang, T. Discriminating catalytically active FeNx species of atomically dispersed Fe-N-C catalyst for selective oxidation of C-H bond. J. Am. Chem. Soc. 2017, 139, 10790-10798. [CrossRef] [PubMed]

22. Strickland, K.; Miner, E.; Jia, Q.; Tylus, U.; Ramaswamy, N.; Liang, W.; Sougrati, M.-T.T.; Jaouen, F.F.; Mukerjee, S. Highly active oxygen reduction non-platinum group metal electrocatalyst without direct metal-nitrogen coordination. Nat. Commun. 2015, 6, 7343. [CrossRef] [PubMed]

23. Wang, M.; Yang, Y.; Liu, X.; Pu, Z.; Kou, Z.; Zhu, P.; Mu, S. The role of iron nitrides in the Fe-N-C catalysis system towards the oxygen reduction reaction. Nanoscale 2017, 9, 7641-7649. [CrossRef] [PubMed]

24. Noh, S.H.; Seo, M.H.; Kang, J.; Okajima, T.; Han, B.; Ohsaka, T. Towards a comprehensive understanding of FeCo coated with N-doped carbon as a stable bi-functional catalyst in acidic media. NPG Asia Mater. 2016, 8. [CrossRef]

25. Toh, R.J.; Sofer, Z.; Pumera, M. Transition Metal Oxides for the Oxygen Reduction Reaction: Influence of the Oxidation States of the Metal and its Position on the Periodic Table. Chemphyschem 2015, 16, 3527-3531. [CrossRef] [PubMed]

26. Choi, C.H.; Baldizzone, C.; Polymeros, G.; Pizzutilo, E.; Kasian, O.; Schuppert, A.K.; Ranjbar Sahraie, N.; Sougrati, M.-T.; Mayrhofer, K.J.J.; Jaouen, F. Minimizing Operando Demetallation of Fe-N-C Electrocatalysts in Acidic Medium. ACS Catal. 2016, 6, 3136-3146. [CrossRef]

27. Ma, Y.; Zhang, H.; Zhong, H.; Xu, T.; Jin, H.; Tang, Y.; Xu, Z. Cobalt based non-precious electrocatalysts for oxygen reduction reaction in proton exchange membrane fuel cells. Electrochim. Acta 2010, 55, 7945-7950. [CrossRef] 
28. Choi, C.H.; Baldizzone, C.; Grote, J.-P.P.; Schuppert, A.K.; Jaouen, F.; Mayrhofer, K.J.J. Stability of Fe-N-C Catalysts in Acidic Medium Studied by Operando Spectroscopy. Angew. Chemie Int. Ed. 2015, 54, 12753-12757. [CrossRef] [PubMed]

29. Roncaroli, F.; Dal Molin, E.S.; Viva, F.A.; Bruno, M.M.; Halac, E.B. Cobalt and iron complexes with N-heterocyclic ligands as pyrolysis precursors for oxygen reduction catalysts. Electrochim. Acta 2015, 174, 66-77. [CrossRef]

30. Armel, V.; Hindocha, S.; Salles, F.; Bennett, S.; Jones, D.; Jaouen, F. Structural descriptors of zeolitic-lmidazolate frameworks are keys to the activity of Fe-N-C catalysts. J. Am. Chem. Soc. 2017, 139, 453-464. [CrossRef] [PubMed]

31. Wu, G.; More, K.L.; Xu, P.; Wang, H.-L.; Ferrandon, M.; Kropf, A.J.; Myers, D.J.; Ma, S.; Johnston, C.M.; Zelenay, P. A carbon-nanotube-supported graphene-rich non-precious metal oxygen reduction catalyst with enhanced performance durability. Chem. Commun. 2013, 49, 3291-3293. [CrossRef] [PubMed]

32. Ganesan, S.; Leonard, N.; Barton, S.C. Impact of transition metal on nitrogen retention and activity of iron-nitrogen-carbon oxygen reduction catalysts. Phys. Chem. Chem. Phys. 2014, 16, 4576-4585. [CrossRef] [PubMed]

33. Singh, D.; Tian, J.; Mamtani, K.; King, J.; Miller, J.T.; Ozkan, U.S. A comparison of N-containing carbon nanostructures $(\mathrm{CN} x)$ and $\mathrm{N}$-coordinated iron-carbon catalysts (FeNC) for the oxygen reduction reaction in acidic media. J. Catal. 2014, 317, 30-43. [CrossRef]

34. Zhang, G.; Chenitz, R.; Lefèvre, M.; Sun, S.; Dodelet, J.-P. Is iron involved in the lack of stability of Fe/N/C electrocatalysts used to reduce oxygen at the cathode of PEM fuel cells? Nano Energy 2016, 29, 111-125. [CrossRef]

35. Jia, Q.; Ramaswamy, N.; Tylus, U.; Strickland, K.; Li, J.; Serov, A.; Artyushkova, K.; Atanassov, P.; Anibal, J.; Gumeci, C.; et al. Spectroscopic insights into the nature of active sites in iron-nitrogen-carbon electrocatalysts for oxygen reduction in acid. Nano Energy 2016, 29, 65-82. [CrossRef]

36. Tylus, U.; Jia, Q.; Strickland, K.; Ramaswamy, N.; Serov, A.; Atanassov, P.; Mukerjee, S. Elucidating Oxygen Reduction Active Sites in Pyrolyzed Metal-Nitrogen Coordinated Non-Precious-Metal Electrocatalyst Systems. J. Phys. Chem. C 2014, 118, 8999-9008. [CrossRef] [PubMed]

37. Jiang, W.-J.; Gu, L.; Li, L.; Zhang, Y.; Zhang, X.; Zhang, L.-J.; Wang, J.-Q.; Hu, J.-S.; Wei, Z.; Wan, L.-J. Understanding the High Activity of Fe-N-C Electrocatalysts in Oxygen Reduction: $\mathrm{Fe} / \mathrm{Fe}_{3} \mathrm{C}$ Nanoparticles Boost the Activity of Fe-Nx. J. Am. Chem. Soc. 2016, 138, 3570-3578. [CrossRef] [PubMed]

38. Chung, H.T.; Cullen, D.A.; Higgins, D.; Sneed, B.T.; Holby, E.F.; More, K.L.; Zelenay, P. Direct atomic-level insight into the active sites of a high-performance PGM-free ORR catalyst. Science 2017, 357, 479-484. [CrossRef] [PubMed]

39. Zeng, L.; Tang, Z.K.; Zhao, T.S. A high-performance alkaline exchange membrane direct formate fuel cell. Appl. Energy 2014, 115, 405-410. [CrossRef]

40. Sun, T.; Jiang, Y.; Wu, Q.; Du, L.; Zhang, Z.; Yang, L.; Wang, X.; Hu, Z. Is iron nitride or carbide highly active for oxygen reduction reaction in acidic medium? Catal. Sci. Technol. 2017, 7, 51-55. [CrossRef]

41. Yu, X.; Manthiram, A. Catalyst-selective, scalable membraneless alkaline direct formate fuel cells. Appl. Catal. B Environ. 2015, 165, 63-67. [CrossRef]

42. Yuan, W.; Xu, X.; Han, F.; Ye, G.; Tang, Y. Developing a passive air-breathing tubular direct methanol fuel cell fed with concentrated methanol. Int. J. Green Energy 2017, 13, 1100-1109. [CrossRef]

43. Chen, C.Y.; Yang, P. Performance of an air-breathing direct methanol fuel cell. J. Power Sources 2003, 123, 37-42. [CrossRef]

44. Queiroz, A.C.; Lima, F.H.B. Electrocatalytic activity and stability of Co and Mn-based oxides for the oxygen reduction reaction in alkaline electrolyte. J. Electroanal. Chem. 2013, 707, 142-150. [CrossRef]

45. Fu, X.; Liu, Y.; Cao, X.; Jin, J.; Liu, Q.; Zhang, J. FeCo-Nxembedded graphene as high performance catalysts for oxygen reduction reaction. Appl. Catal. B Environ. 2013, 130-131, 143-151. [CrossRef]

46. Fang, X.; Jiao, L.; Yu, S.H.; Jiang, H.L. Metal-Organic Framework-Derived FeCo-N-Doped Hollow Porous Carbon Nanocubes for Electrocatalysis in Acidic and Alkaline Media. ChemSusChem 2017, 10, 3019-3024. [CrossRef] [PubMed]

47. Zheng, Y.; Yang, D.S.; Kweun, J.M.; Li, C.; Tan, K.; Kong, F.; Liang, C.; Chabal, Y.J.; Kim, Y.Y.; Cho, M.; et al. Rational design of common transition metal-nitrogen-carbon catalysts for oxygen reduction reaction in fuel cells. Nano Energy 2016, 30, 443-449. [CrossRef] 
48. Yang, H.B.; Miao, J.; Hung, S.-F.; Chen, J.; Tao, H.B.; Wang, X.; Zhang, L.; Chen, R.; Gao, J.; Chen, H.M.; et al. Identification of catalytic sites for oxygen reduction and oxygen evolution in N-doped graphene materials: Development of highly efficient metal-free bifunctional electrocatalyst. Sci. Adv. 2016, 2. [CrossRef] [PubMed]

49. Ramaswamy, N.; Mukerjee, S. Influence of Inner-and Outer-Sphere Electron Transfer Mechanisms during Electrocatalysis of Oxygen Reduction in Alkaline Media. J. Phys. Chem. C 2011, 115, 18015-18026. [CrossRef]

50. Singh, M.R.; Papadantonakis, K.; Xiang, C.; Lewis, N.S. An electrochemical engineering assessment of the operational conditions and constraints for solar-driven water-splitting systems at near-neutral $\mathrm{pH}$. Energy Environ. Sci. 2015, 8, 2760-2767. [CrossRef]

51. Schmidt, H.; Vielstich, W. Einfluß von Edelmetall-Mischkatalysatoren auf die anodische Oxydation von Methanol und Formiat. Fresenius Z. Anal. Chem. 1967, 224, 84-93. [CrossRef]

52. Lima, F.H.B.; Profeti, D.; Chatenet, M.; Riello, D.; Ticianelli, E.A.; Gonzalez, E.R. Electro-oxidation of Ethanol on $\mathrm{Rh} / \mathrm{Pt}$ and $\mathrm{Ru} / \mathrm{Rh} / \mathrm{Pt}$ Sub-monolayers Deposited on Au/C Nanoparticles. Electrocatalysis 2010, 1, 72-82. [CrossRef]

53. Kristian, N.; Wang, X. Ptshell-Aucore/C electrocatalyst with a controlled shell thickness and improved Pt utilization for fuel cell reactions. Electrochem. Commun. 2008, 10, 12-15. [CrossRef]

54. Schmidt, T.J.; Gasteiger, H.A.; Stäb, G.D.; Urban, P.M.; Kolb, D.M.; Behm, R.J. Characterization of High-Surface-Area Electrocatalysts Using a Rotating Disk Electrode Configuration. J. Electrochem. Soc. 1998, 145, 2354-2358. [CrossRef]

55. Gulzow, E.; Giilzow, E. Alkaline fuel cells: A critical view. J. Power Sources 1996, 61, 99-104. [CrossRef]

56. Paganin, V.A.; Ticianelli, E.A.; Gonzalez, E.R. Development and electrochemical studies of gas diffusion electrodes for polymer electrolyte fuel cells. J. Appl. Electrochem. 1996, 26, 297-304. [CrossRef]

(C) 2018 by the authors. Licensee MDPI, Basel, Switzerland. This article is an open access article distributed under the terms and conditions of the Creative Commons Attribution (CC BY) license (http:/ / creativecommons.org/licenses/by/4.0/). 